\title{
Vergi Mükelleflerinin Vergi Denetimi Algıları: Çorum Örneği
}

Metin SA $\breve{G}$ LAM, Department of Public Finance, Faculty of Economics and Administrative Sciences, Hitit University, Turkey; e-mail: metinsaglam@hitit.edu.tr

Deniz AYTAÇ, Department of Public Finance, Faculty of Economics and Administrative Sciences, Hitit University, Turkey; e-mail: denizaytac@hitit.edu.tr

\section{Tax Audit Perception of Taxpayers: A Case of Çorum}

\begin{abstract}
The basic economic theory of tax compliance deals with the question 'why taxpayers pay taxes'. But a psychological tax contract explains tax complaince as an interaction between tax payers and the tax authority. Based on psychological tax contract theory, taxpayers' willingness to pay their taxes and willing to honestly declare their income, raised, when the tax official streat them with respect. This study aims to examine the hypothesis of psychological tax contract by using a survey which is applied to members of Çorum Chamber of Commerce and Industry.

Keywords : Psychological Tax Contract, Tax Audit Perception, Tax Compliance.

JEL Classification Codes : $\quad$ H20, H29.

\section{$\ddot{\mathbf{O z}}$}

Vergi uyumunun temel ekonomik teorisi, vergi mükelleflerinin neden vergi ödediği sorusu ile ilgilenir. Psikolojik vergi sözleşmesi ise vergi uyumunu, mükellefler ve vergi otoritesi arasındaki ilişki olarak tanımlar. Bu kapsamda psikolojik vergi sözleşmesi teorisine göre, vergi mükelleflerinin vergilerini ödeme arzuları ve gelirlerini dürüstçe beyan etmeleri vergi elemanlarının kendilerine saygı gösterdiklerinde artar. Bu çalışmanın amacı psikolojik vergi sözleşmesinin bu varsayımını Çorum Ticaret ve Sanayi Odası üyelerine uygulanan bir anket ile incelemektir.
\end{abstract}

Anahtar Sözcükler $\quad$ : Psikolojik Vergi Sözleşmesi, Vergi Denetim Algısı, Vergi Uyumu. 


\section{Giriş}

Değişen ekonomik konjonktür ve devlet anlayışı doğrultusunda, kamu sektörünün ekonomi içinde değişen ve gelişen payı, kamu harcamaları ile birlikte kamu finansman ihtiyacını da arttırmıştır. Bu artış günümüz modern devletinin temel gelir kaynağı olan vergilerin zamanında ve tam olarak ödenmesi ihtiyacını gündeme getirmektedir. $\mathrm{Bu}$ kapsamda mükelleflerin vergi ahlakı, vergiye uyumu/uyumsuzluğu mali literatürün temel konularından birini oluşturmaktadır. Vergi uyumu farklı teoriler kapsamında farklı değişkenlerle ilişkilendirilse de literatürde bu konudaki temel çalışma Allingham ve Sandmo tarafından gerçekleştirilmiştir. Çalışmada vergi denetim ve cezaları ile vergi uyumu arasındaki ilişki ortaya konmuştur. İlerleyen süreçte ise mali literatür, vergi uyumunda zorunlu ve ideolojik uyumun birlikte etkili olduğu ve denetim ve cezalar kadar vergi otoritesinin mükelleflere olan muamelesinin de vergi uyumunda önemli olduğu bulgusunda ulaşmıştır. Bu bulgular, vergi tarafları arasındaki pozitif muamele ve saygının, mükelleflerin denetim algısını etkileyerek, vergi algısı ve vergi uyum davranışının oluşmasında olumlu etki sağlayacağını göstermektedir. Bu kapsamda bu çalışmada Türkiye'deki mevcut denetim sistemi dâhilinde vergi uyumunu sağlamak amacı ile yapılan vergi denetimlerinin mükelleflerin denetim algısını nasıl etkilediği incelenecektir.

\section{2. İlgili Literatür}

Vatandaşların devlete olan borçlarını (vergi) ödeme konusundaki içsel motivasyonu olarak tanımlanan vergi ahlakı (Torgler, 2011: 5), kamu sektörünün etkinliğinin bir parçası olarak vergi kayıp ve kaçakları dolayısı ile kayıtdışı ekonominin boyutu üzerinde etkili (Shneider, 2011: 89) olmakla birlikte, sadece kurumsal şartlara değil vergi otoritesinin mükelleflere muamelesine, bireylerin siyasi ve hukuki sisteme güvenine bağlıdır (Shneider, 2011: 362). Vergi ahlakı kapsamında vergi uyumu ise, bireyin mükellefi olduğu vergileri gönüllü olarak ödemesi, vergi beyannamesinin verildiği dönemde uygulamada olan vergi yasaları, yönetmelikler ve yargı kararlarına uygun olarak, vergi ile ilgili gerekli bilgilerin zamanında açıklanması, mükelleflerin yükümlülüklerini bir yaptırım olmaksızın kendiliğinden yerine getirmesi olarak tanımlanır (Roth vd., 1989: 21). Bu tanım kapsamında ele alınan vergi ahlakının önemi, özellikle artan kamu finansman ihtiyacı karşısında vergilerin eksiksiz ve zamanın ödenmesi ihtiyacını birçok gelişmiş ve gelişmekte olan ülke açısından giderek arttırmış ve vergi uyumu üzerinde etkili olan değişkenlerin bilinmesi, uyumu arttırma açısından önem arz eder duruma gelmiştir. Bu önem paralelinde 1900'li yılların ortalarından itibaren mükelleflerin vergileri kendiliğinden gönüllü olarak ödeme (uyum) yada ödememe (uyumsuzluk) kararları üzerinde etkili olan faktörleri ele alan araştırmaların literatür içinde ağırlık kazandığı görülmektedir. Söz konusuliteratürde yer alan çalışmaların başında Allingham ve Sandmo'nun (1972) çalışmaları gelmektedir. Vergi uyumu konusundaki literatürün temeli sayılabilecek bu çalışmada, Becker (1968)'ın suçun 
ekonomik analizi teorisi, Allingham ve Sandmo'nun (1972) tarafindan fayda maksimizasyonu kapsamında vergi uyumu analizinde kullanılmış ve ekonomik caydırıcılık modelinin temelini oluşturmuştur. Ekonomik caydırıcılık modeli vergi denetim olasılığı ve uygulanan cezaların vergi uyumu, vergi kayıp ve kaçakları üzerinde etkili olduğu varsayımına dayanır. Ekonomik caydırıcılık modeli kapsamında vergi uyumunu etkileyen temel faktör olan vergi denetimi Organ (2008)'ın Grampert (2002) den yaptığı alıntıda; ' genel olarak vergi mükellefinin ödeyeceği vergisini doğru olarak tespit edip etmediğinin, vergi yükümlülüğ̈̈nü bildirip bildirmediğinin, vergi mevzuatı ve genel anlamda vergi sistemine göre diğer yükümlülük/sorumluluklarını yerine getirip getirmediğinin incelenmesi' olarak ifade edilmiştir.

Bu tanım kapsamında vergi denetiminden belenen iki temel etki vardır:

1- Denetim sürecinde saptanan vergi uyumsuzluğu nedeni ile mükelleflere kesilen vergi cezaları ve uygulanan faiz nedeni ile ortaya çıkan doğrudan kamu geliri artış etkisi,

2- Denetim geçiren mükelleflerin gelecekteki vergi uyumu ile ilgili tutum ve davranışlarda değişime neden olacak davranışsal etkidir. Bu davranışsal etkiler koruyucu düzenleyici etki ve denetim geçirmeyen mükelleflere yayılan caydırıcı etki olarak ifade edilebilir (Feld \& Frey, 2006: 5-6).

Denetim olasılığı ve cezaların davranışsal etkilerini inceleyen ekonomik caydırıcılık modeli kapsamında yapılan birçok çalışmada, Allingham ve Sandmo'nun teorisini destekler nitelikte sonuçlara ulaşılmıştır. $\mathrm{Bu}$ kapsamda Andreoni, Erard ve Feinstein (1998) ve Slemrod ve Yitzhaki (2002) çalışmalarında -ceterisparibus - yüksek cezalar ile düşük vergi kaçağı ve ceterisparibus yüksek denetim olasılığı ile düşük vergi kaçağı arasında anlamlı ilişkinin olduğu sonucuna varmışlardır. Ekonomik caydırıcılık modelini destekler nitelikteki bu çalışmaların yanı sıra literatürde belirsiz ve çelişkili sonuçlara varılan incelemelerde yer almaktadır. Örneğin Spicer ve Lundstedt (1976), Friedland (1982), Elffers, Weigel ve Hessing (1987), Varma ve Doob (1998) çalışmalarında denetim olasılığı ile vergi uyumu arasındaki ilişinin belirsiz olduğu sonucuna varılmıştır. Söz konusu çalışmalardaki belirsizlik farklı çalışmalarda yerini teorinin tersine olan çelişkili sonuçlara bırakmıştır. Farklı ülke uygulamalarının ele alındığı bu çalışmalarda düşük caydırıcılığın (denetim yoğunluğunun ve cezaların düşük) olduğu ülkelerde vergi uyumunun yüksek olduğu sonucuna ulaşılmıştır (Graetz \& Wilde 1985; Alm, McClelland ve Schulze 1992 ve Pommerehne ve Frey 1992, Feld \& Frey, 2002). Bu çelişkili sonuçlar ekonomik caydırıcı model kapsamında denetim yoğunluğu ve ceza değişkenlerinin yanı sıra ampirik çalışmalarda özelikle sosyo-demografik değişkenlerinde analize dahil edilmesini gündeme getirmiştir. Polinsky ve Shavell (2000) yılındaki çalışmalarında vergi uyumu üzerinde hukuki yaptırımların alternatifi olan bireysel davranışları kapsayan sosyal normların etkili 
olduğunu ileri sürmüşlerdir. Mükellefler vergilerini öderler çünkü doğru olanı yapma eğilimindedirler. $\mathrm{Bu}$ eğilim ise davranışsal, bireysel (inanç) ve sosyal normlarla yakından ilişkilidir (Walsh, 2012: 4). Fakat söz konusu değişkenlerinin dahil edildiği çalışmalar dahi vergi uyumunu açıklamada yeterli olamamıştır. Bu kapsamda Frey ve Feld (2002) çalışmalarında caydırıcı ve sosyo demografik faktörlerle açıklanamayan vergi uyumuna, vergi otoritesi ve mükellef ilişkilerinin de dahil edilmesini önermişlerdir. Psikolojik vergi sözleşmesi (Psychological Tax Contrat) temelinden hareket eden çalışmada, vergi otoritesi/devlet ile mükellefler/vatandaşlar arasında bir sözleşmenin olduğu varsayılır.

\section{Psikolojik Vergi Sözleşmesi ve Denetim Algısı}

Psikolojik vergi sözleşmesi diğer resmi sözleşmelerden farklı olarak tarafların önceden açık ve maddi yaptırımlar konusunda hem fikir olmaları nedeni ile uydukları kurallardan oluşan sözleşmelerdir. Psikolojik vergi sözleşmelerinde cezalar caydırıcılık açısından önemli bir rol oynamakla birlikte, vergi ahlakı ve vergi uyumu üzerinde, ödüllendirme, vergi prosedürlerinin adil olarak işlemesi ve vergi taraflarının karşılıklı davranışlarının önemli etkisi bulunmaktadır (Feld \& Frey, 2006: 6-8). Psikolojik vergi sözleşmesi öncelikle vergilerin kısmi gönüllülük (quasivoluntary) davranışı ile ödendiği görüşüne dayanır. Levi tarafından yapılan çalışmada vergi uyumu zorunlu (cebri) ve gönüllü (ideolojik, normatif) uyum olarak iki kutuba ayrılmıştır. Zorunlu uyum, cebrin olmadı̆̆ında uyumunda olmayacağı görüşünden hareketle, vergisini ödemeyen yada düşük beyanda bulunan mükelleflerin cezalandırılması temeline dayanır. Gönüllü uyum ise, uyumsuzluk nedeni ile mükelleflerin herhangi bir cebri uygulamaya maruz kalmamalarına rağmen, doğru olanı yapma düşüncelerinin sonucu olarak ortaya çıkan davranıştır. Gönüllü uyumda bireyler kimi zaman normatif ya da ideolojik kanaatleri doğrultusunda hareket eder. Levi, North'a atfen yaptığı açıklamada ideolojinin, davranışları belirleyen bireysel inanış ve değerlerden oluştuğunu ifade etmektedir. Vergilemede ise ideoloji vergi uyumunu, mevcut adalet normlarının tanımlanması yolu ile etkiler. Bu kapsamda mükellefler kamusal malları finanse eden vergilerin adil dağıldığı ve adil dağılan vergi paylarının diğer mükellefler tarafından eksiksiz ödendiği görüşüne sahipse herhangi bir cebri unsura gerek kalmaksızın vergi uyumu gerçekleşir. Kısmi gönüllü uyum ise gönüllü uyum ile birlikte cebri uyumu da kapsayan bir yapıya sahiptir. Cebridir, çünkü mükelleflerin vergi uyumsuzluğu tespit edildiğinde bu uyumsuzluk cezalandırılır. Gönüllüdür, çünkü bireyler vergi otoritesi ve diğer mükelleflerin adil davrandığ kabulü ile vergisini tam ve zamanında öder (Levi, 1988: 50-58). Kısmi gönüllü uyum mükellefin devlet ile arasında var olduğu kabul edilen sözleşmeye uygun davranması ve sözleşmenin tüm taraflarının kendilerine düşen yükümlülüğü yerine getirmesine bağlıdır. Bu kapsamda psikolojik vergi sözleşmesi perspektifinden hareket eden Feld ve Frey (2002; 2006; 2010), vergilemenin kısmi gönüllü değişime dayandığı, mükelleflerle devlet/ vergi otoritesi arasında duygusal bağları, bağlılıkları, görev ve hakları kapsayan zımni sözleşmenin varlığı kabulüne dayanır. Bu sözleşme sadece mali değişimi 
değil, pozitif muamele, saygı, siyasi karar alma süreçlerine katılım gibi unsurları da kapsar. Böylece mükelleflerin vergi uyumu hükümet politikaları, kamu hizmetleri ve vergi otoritesinin mükelleflere muamelesi ile yakından ilgilidir. Burada bu çalışmanın da temelini oluşturan ana unsur vergi otoritesinin mükelleflere muamelesidir. Vergi otoritesinin mükelleflere muamelesi taraflar arasındaki dayanışmanın düzeyini etkiler. Vergi otoritesinin mükellefe saygılı davranışı mükellefin denetim algısını oluşturarak vergi algısı ve uyumunu şekillendirir. Bu kapsamda vergi otoritesinin mükellefe saygılı muamelesi temelde iki bileşenden oluşur. Bunlardan ilki vergi otoritesi ve mükellefler arasındaki sözleşmeye dayalı olarak denetim sürecinin saydam olması. Diğeri ise psikolojik vergi sözleşmesi kapsamında sözleşmenin eşit düzey tarafı olarak hissettirilmesidir (Feld \& Frey 2006: 4). Böylece mükellef ile vergi otoritesi arasındaki saygılı muamele ilişkisi mükellefin denetim algısını olumlu etkileyerek, gelecekteki vergi uyumu ile ilgili tutum ve davranışlarda değişime neden olacak, denetim geçirmeyen mükelleflerde olumlu algıların oluşmasını sağlayarak uzun vadede vergi uyumunu arttıracaktır.

Bu kapsamda yapılan çalışmalarda teoriyi destekleyen sonuçlara varılmıştır. Feld ve Frey (2002), karar alma süreçlerinde referandumun kullanıldığı 26 İsveç kantonunu kapsayan çalışmalarında, vergi otoritesinin mükelleflere saygılı davranışının otoriter (caydırıc1) davranışa göre vergi uyumu üzerinde daha etkili olduğu tespitinde bulunmuşlardır. Brithwaite ise 2003 yılında Avustralya Vergi Ofisi Uyum modeli çalışmasında vergi idaresi ve mükellef arasındaki diyalog, ikna, karşılıklı anlayış ve saygılı muamelenin vergi algısını olumlu etkileyerek vergi uyumunu artırdığı sonucuna ulaşmıştır.

Türkiye'yi kapsayan çalışmalarda ise doğrudan denetim algısı yerine vergi algısı kapsamında denetim ile ilgili soruların mükellefe yöneltildiği ve bu kapsamda bazı değerlendirmelerin yapıldığı görülmüştür. Örneğin 1993 yılında Manisa ilinde Muter, Sakınç ve Çelebi tarafından yapılan ve vergi mükelleflerinin denetim elemanlarının davranışları hakkındaki görüşlerine de değinilen çalışmada; katılımcıların \%41,4'ünün incelemenin ciddiyetine uygun tarafsız davrandıklarını, \%38,6'nın denetin elemanlarının hatalar konusunda uyarıda bulunduğunu, \%13,1'idenetim esnasında küçük düşürüldüğünü, \%3,1'si denetim elemanlarının kimi zaman anlayışlı kimi zaman ters davrandıklarını belirtmişlerdir.

Yeniçeri (2004) tarafından yapılan ve İstanbul ilinin bazı ilçelerini kapsayan çalışmada ise, vergi mükelleflerinin \%18, ' 'inin denetimin çok sık yapıldığını, \%59,6'sı ise denetimlerin çok sık olmadığını beyan etmişleridir. Ayrıca, mükelleflerin \%48,3’ü vergi denetimlerinin ve cezalarının vergisini ödenmesi açısından bir baskı unsuru olarak görmediklerini, \%41,0’1 ise bir baskı unsuru olarak gördüklerini ifade etmişlerdir. 
Tuay ve Güvenç (2007) tarafindan yapılan çalışma ise, vergi mükelleflerin çoğunluğu olan \%53,3'ü nün yeterince denetlenmedikleri görüşünde olduğu sonucuna ulaşmıştır.

Çiçek, Karakaş ve Yıldız tarafindan Güneydoğu Anadolu bölgesinde vergi yükümlülerini kapsayan 2008 yılındaki çalışmada ankete katılanların \%47,8'i kamu finansman karşılanması için vergi denetimlerini arttırması gerektiğini ifade etmişlerdir. Ayrıca denetim ile ilgili diğer anket sorularına katılımcıların \%32,5'i denetimin ciddiyetine uygun olarak tarafsız yapıldığı yanıtını vermiş, davranıyorlar, \%26,3'ü vergi denetim elemanlarının mükelleflere hatalarını gösterip uyarıda bulunarak cezaya muhatap olmalarını engellediğini dile getirmiş, \%22,0'si ise denetim esnasında denetçilerin mükelleflerin işini aksatıp, müşteri ve çalışanlarının yanında küçük düşürüldüğünü ifade etmiştir.

\section{Araştırma Hakkında Genel Bilgiler}

\subsection{Araştırmanın Amacı}

Tüm bu incelemeler 1şığında bu çalışmanın amacı literatürdeki diğer çalışmalardan farklı olarak cebri ve ideolojik gönüllülüğün vergi uyumu üzerindeki etkisini incelemek yerine vergi otoritesinin mükelleflere muamelesi kapsamında oluşan ve uzun dönemde psikolojik vergi sözleşmesi varsayımlarına dayalı olarak gerçekleşecek vergi uyumunu etkileyecek olan denetim algısını araştırmaktır.

\subsection{Araştırmanın Yöntemi}

Araştırma verilerinin toplanmasında anket yöntemi kullanılmıştır. Ağırlıklı olarak çoktan seçmeli sorular kullanılmıştır. Mükellefin yaşı sorusu açık uçlu bırakılmış ve sonradan tarafımızdan gruplandırılmıştır. Anket sonucu elde edilen veriler, istatistik paket programı SPSS 15.0 (Statistical Package for Social Sciences) ile analiz edilmiştir. Burada anketin seçilmiş soruları ve cevapları yüzde ve çapraz tablo analizleri ile değerlendirmeye tabi tutulmuştur. (Ankete ait betimleyici istatistikler Ek Tablo: 1'de yer almaktadır.)

\subsection{Araştırmanın Kapsamı ve Örnek Kitle Seçimi}

Araştırmanın evrenini Çorum ilinde Ticaret ve Sanayi odasına kayıtlı vergi mükellefleri oluşturmaktadır. Odadan alınan bilgilere odaya kayıtlı üye sayısı 3467'dir. Araştırmanın ana kitlesini temsil etme özelliğine sahip örnek kitle aşağıdaki formül yardımı ile tespit edilmiştir. Buna göre: 


$$
\begin{aligned}
& n=\frac{t^{2} \frac{p x q}{d^{2}}}{1+\frac{1}{N} x t^{2} x \frac{p x q}{d^{2}}} \\
& \mathrm{~N}=\text { Evren (Ana kitle) büyüklüğü, } \\
& \mathrm{n}=\text { Örnek kitle büyüklüğü, } \\
& \mathrm{p}=\text { Olayın görülme sıklığı, } \\
& \mathrm{q}=\text { Olayın görülmeme sıklığı (1-p), } \\
& \mathrm{t}=\text { Güven düzeyi (t tablo değeri), } \\
& \mathrm{d}=\text { Tolerans düzeyi’ni }
\end{aligned}
$$

temsil etmektedir (Şahin, 2012: 126). Bu formüle göre, \%5 güven düzeyi ve $\% 5$ 'lik tolerans düzeyi ile n 346 bulunmuştur. Bu kapsamda 450 sayıda üyeye anket dağıtılmış, dağıtılan anketlerden 278 sayıda dönüş olmuştur. 261 adet anket değerlendirilebilir bulunmuş ve çalışma 261 adet anket formunun değerlendirilmesiyle tamamlanmıştır.

\section{Araştırmanın Bulguları}

\subsection{Ankete Katılan Mükellefler Hakkında Genel Bilgiler}

Ankete katılan mükelleflerin cinsiyet, yaş grupları ve öğrenim durumlarına ilişkin genel bilgiler Tablo: 1,2 ve 3'te verilmiştir.

Tablo: 1

\section{Mükelleflerin Cinsiyet Türüne Göre Dağılımı}

\begin{tabular}{|l|c|c|c|}
\hline Cinsiyetiniz? & $\begin{array}{c}\text { Sıklık } \\
(\boldsymbol{n})\end{array}$ & $\begin{array}{c}\text { Yüzde } \\
(\boldsymbol{\%})\end{array}$ & $\begin{array}{c}\text { GeçerliYüzde } \\
(\boldsymbol{\%})\end{array}$ \\
\hline Kadın & 27 & 10,3 & 10,3 \\
\hline Erkek & 234 & 89,7 & 89,7 \\
\hline Toplam & 261 & 100,0 & 100,0 \\
\hline
\end{tabular}


Araştırmaya katılan vergi mükelleflerinin cinsiyet türüne göre dağılımı Tablo: 1'de görülmektedir. Dağılım \%89,7 “erkek", \%10,3 “kadın” şeklindedir. Buna göre ankete katılan mükelleflerin büyük kısmı "erkek” mükelleflerden oluşmaktadır.

Tablo: 2

\section{Mükelleflerin Yaş Gruplarına Göre Dağılımı}

\begin{tabular}{|c|c|c|c|}
\hline Yaşınız? & $\begin{array}{c}\text { Siklkk } \\
(n)\end{array}$ & $\begin{array}{l}\text { Yüzde } \\
(\%)\end{array}$ & $\begin{array}{c}\text { GeçerliYüzde } \\
(\%)\end{array}$ \\
\hline 18-35 Yaş Grubu & 95 & 36,4 & 37,1 \\
\hline 36-50 Yaş Grubu & 131 & 50,2 & 51,2 \\
\hline 51 ve üzeri Yaş Grubu & 30 & 11,5 & 11,7 \\
\hline Toplam & 256 & 98,1 & 100,0 \\
\hline Kayı" * & 5 & 1,9 & \\
\hline Toplam & 261 & 100,0 & \\
\hline
\end{tabular}

* Kayıp, ankette ilgili soruyu cevaplandirmayan kişi saylsı.

Mükelleflerin yaş faktörü itibariyle dağılımı Tablo 2'de görülmektedir. Yaş sorusu açık uçlu olarak sorulmuş sonradan gruplandırılmıştır. Gruplandırma 18-35 genç yaş grubu, 36-50 orta yaş grubu, 51 yaş ve üzeri ise orta yaş üstü grup şeklinde yapılmıştır. Buna göre ankete katılan mükelleflerin \%37,1'i "genç yaş grubu", \%51,2'si "orta yaş grubu”, \%11,7'si ise "orta yaş üstü grubu" oluşturmaktadır. Burada ankete katılan mükelleflerin ağırlıklı olarak "orta yaş grup”tta olduğu görülmektedir.

Tablo: 3

Mükelleflerin Öğrenim Durumuna Göre Dağılımı

\begin{tabular}{|c|c|c|c|}
\hline Ö̆̆renim durumunuz nedir? & $\begin{array}{c}\text { Siklık } \\
\text { (n) }\end{array}$ & $\begin{array}{c}\text { Yüzde } \\
(\%)\end{array}$ & $\begin{array}{c}\text { GeçerliYüzde } \\
(\%)\end{array}$ \\
\hline İlköğretim & 38 & 14,6 & 14,6 \\
\hline Lise & 87 & 33,3 & 33,5 \\
\hline Yüksekokul (Önlisans) & 38 & 14,6 & 14,6 \\
\hline Üniversite (Lisans) & 97 & 37,2 & 37,3 \\
\hline Toplam & 260 & 99,6 & 100,0 \\
\hline Kayıp & 1 & 0,4 & \\
\hline Toplam & 261 & 100,0 & \\
\hline
\end{tabular}

Mükelleflerin öğrenim durumuna göre dağılımı Tablo 3'te görülmektedir. Ankete katılan mükelleflerin \%14,6's1 “ilköğretim”, \%33,5'i “lise”, \%14,6’s1 “önlisans" ve \%37,3'ü “lisans" mezunudur. Öğrenim durumu bakımından her öğrenim seviyesinden araştırmaya katılan mükellef bulunmaktadır. Bununla birlikte önlisans ve lisans mezunlarının toplamı \%51,9 oranına ulaştığından, ankete katılan mükelleflerin yarısının "yükseköğretim" mezunu olduğu anlaşılmaktadır. 


\subsection{Ankete Katılan Mükelleflerin Vergi, Vergi Sistemi ve Vergi Yükü Algiları}

Ankete katılan mükelleflerin vergiye yükledikleri anlam ve ya vergi algıları, adalet açısından vergi sistemine ilişkin algıları ve taşıdıkları vergi yükü bakımından sahip oldukları algıları Tablo: 4, 5 ve 6'da verilmiştir.

Tablo: 4

Mükellefler Göre Verginin Anlamı

\begin{tabular}{|c|c|c|c|}
\hline Verginin anlamı size göre nedir? & $\begin{array}{c}\text { Stklık } \\
(n)\end{array}$ & $\begin{array}{c}\text { Yüzde } \\
(\%)\end{array}$ & $\begin{array}{c}\text { GeçerliYüzde } \\
(\%)\end{array}$ \\
\hline Vatandaşlık görevidir & 128 & 49,0 & 49,2 \\
\hline Kamu hizmetleri için bir ödemedir & 48 & 18,4 & 18,5 \\
\hline Devletin yaşaması için bir ödemedir & 62 & 23,8 & 23,8 \\
\hline Gereksiz bir ödemedir & 8 & 3,1 & 3,1 \\
\hline Zorunlu bir ödemedir & 14 & 5,4 & 5,4 \\
\hline Toplam & 260 & 99,6 & 100,0 \\
\hline Kayıp & 1 & 0,4 & \\
\hline Toplam & 261 & 100,0 & \\
\hline
\end{tabular}

Mükelleflerin vergiye yükledikleri anlamı araştıran soruya verilen cevapların sıklık ve yüzde dağılımı Tablo: 4'te verilmiştir. Buna göre mükelleflerin \%49,2'si "vatandaşlık görevi”, \%18,5'i“"kamu hizmetleri için bir ödeme”, \%23,8'i “devletin yaşaması için bir ödeme", \%5,4’ü "zorunlu bir ödeme", \%3,1'i ise, "gereksiz bir ödeme" olarak vergiyi anlamlandırmışlardır. Vergiyi olumsuz olarak gören ve gereksiz ödeme olarak nitelendiren mükellefler çok düşük orandadır. Vergiyi zorunlu ödeme olarak nitelendiren ve nötr olarak yaklaşan mükelleflerin oranı da \%5,4 gibi düşük bir orandadır. Buna karşılık vergiyi olumlu bir değer yargısı ile anlamlandıran mükelleflerin ilk üç seçenekte yoğunlaştıkları görülmektedir. Bu üç seçeneğin toplamı \%91,5 oranındadır. Sonuç olarak ankete katılan mükellefler vergiyi olumlu algılamaktadırlar.

Tablo: 5

Adalet Açısından Mükelleflere Göre Vergi Sistemi Algısı

\begin{tabular}{|l|c|c|c|}
\hline Türkiye'de vergi sistemi size göre nasıldır? & $\begin{array}{c}\text { Sıklık } \\
\text { N }\end{array}$ & $\begin{array}{c}\text { Yüzde } \\
\%\end{array}$ & $\begin{array}{c}\text { Geçerli } \\
\text { Yüzde \% }\end{array}$ \\
\hline Adaletsiz & 195 & 74,7 & 74,7 \\
\hline Kismen Adaletli & 52 & 19,9 & 19,9 \\
\hline Adaletli & 14 & 5,4 & 5,4 \\
\hline Toplam & 261 & 100,0 & 100,0 \\
\hline
\end{tabular}


Mükelleflerin adalet açısından ülkemizdeki vergi sistemine ilişkin algılarını araştıran soruya verdikleri cevapların sıklık ve yüzde dağılımı Tablo: 5 'te verilmiştir. Buna göre vergi sistemi için mükelleflerin \%74,7'si “adaletsiz”, \%19,9'u “kısmen adaletli”, \%5,4'ü “adaletli” cevabı vermişlerdir. Ankete katılan mükelleflerin büyük çoğunluğu ülkemizdeki vergi sistemini "adaletsiz" olarak değerlendirmektedirler.

Tablo: 6

Mükelleflere Göre Türkiye'de Vergi Yükü

\begin{tabular}{|l|c|c|c|}
\hline Türkiye'de vergi oranları/vergi yükü size göre nasıldır? & $\begin{array}{c}\text { Sıklık } \\
(\boldsymbol{n})\end{array}$ & $\begin{array}{c}\text { Yüzde } \\
(\boldsymbol{\%})\end{array}$ & $\begin{array}{c}\text { Geçerli Yüzde } \\
(\boldsymbol{\%})\end{array}$ \\
\hline Düşük & 6 & 2,3 & 2,3 \\
\hline Normal & 23 & 8,8 & 8,8 \\
\hline Yüksek & 232 & 88,9 & 88,9 \\
\hline Toplam & 261 & 100,0 & 100,0 \\
\hline
\end{tabular}

Mükelleflerin ülkemizdeki vergi oranlarına veya taşıdıkları vergi yüküne ilişkin algılarını araştıran soruya verilen cevapların sıklık ve yüzde dağılımı Tablo: 6'da verilmiştir. Buna göre vergi oranları/vergi yükü için mükelleflerin \%2,3'ü “düşük”, \%8,8'i "normal”, \%88,9'u “yüksek” cevabı vermişlerdir. Ankete katılan mükelleflerin büyük çoğunluğu ülkemizdeki vergi oranlarını ve taşıdıkları vergi yükünü "yüksek" olarak değerlendirmektedirler.

\subsection{Mükelleflerin Vergi Denetimi Algıları ve Vergi Denetimine Bakışlarına İlişkin Bulgular}

Ankete katılan mükelleflerin vergi denetimi algıları ve vergi denetimine bakışlarına ilişkin bulgular aşağıda ele alınmaktadır.

Tablo: 7

Mükelleflere Göre Vergi Denetiminin Amacı

\begin{tabular}{|l|c|c|c|}
\hline Vergi denetiminin amacı size göre nedir? & $\begin{array}{c}\text { Stkllk } \\
(\boldsymbol{n})\end{array}$ & $\begin{array}{c}\text { Yüzde } \\
(\boldsymbol{\%})\end{array}$ & $\begin{array}{c}\text { Geçerli Yüzde } \\
(\%)\end{array}$ \\
\hline Mükellefin vergisini ödemesini sağlamak & 30 & 11,5 & 11,5 \\
\hline Vergi kayıp ve kaçağını önlemek & 120 & 46,0 & 46,0 \\
\hline Kayıtdışı ekonomiyi önlemek & 65 & 24,9 & 24,9 \\
\hline Vergi kaçıranları yakalamak & 15 & 5,7 & 5,7 \\
\hline Mükelleflere gözdağı vermek & 31 & 11,9 & 11,9 \\
\hline Toplam & 261 & 100,0 & 100,0 \\
\hline
\end{tabular}


Mükelleflerin vergi denetiminin amacına ilişkin düşüncelerini araştıran soruya verilen cevapların sıklık ve yüzde dağılımı Tablo: 7'de verilmiştir. Buna göre mükelleflerin \%46'sı "vergi kayıp ve kaçağını önlemek", \%24,9'u "kayıt dışı ekonomiyi önlemek", \%11,9'u "mükellefe gözdağ vermek", \%11,5'i "mükellefin vergisini ödemesini sağlamak", \%5,7'si de "vergi kaçıranlart yakalamak" cevabını vermişlerdir. Mükelleflerin büyük çoğunluğunun (\%11,9'luk "mükellefe gözdă̆l vermek" seçeneği dışında kalanlar) vergi denetimlerinin amacı hakkında olumlu bir yargıya veya algıya sahip oldukları anlaşılmaktadır.

\section{Tablo: 8}

\section{Mükelleflerin Vergi Denetimi Geçirmeleri Durumunda Denetimin Sonucuna İlişkin} Düşünceleri

\begin{tabular}{|c|c|c|c|}
\hline Vergi denetimi için işletmenize gelindiğinde ne düşünürsünüz? & \begin{tabular}{|c|c|} 
Siklık \\
$(n)$
\end{tabular} & $\begin{array}{l}\text { Yüzde } \\
(\%)\end{array}$ & $\begin{array}{l}\text { Geçerli Yüzde } \\
(\%)\end{array}$ \\
\hline Vergiye ilişkin ödevlerimi yerine getirdiğim için rahat olurum & 95 & 36,4 & 36,5 \\
\hline $\begin{array}{l}\text { Vergiye ilişkin ödevlerimi yerine getirsem de bir eksiklik çıkar diye tedirgin } \\
\text { olurum }\end{array}$ & 76 & 29,1 & 29,2 \\
\hline $\begin{array}{l}\text { Vergiye ilişkin ödevleri yapmış olmak yetmez, denetim elemanı illa ki bir } \\
\text { eksiklik bulacağı için tedirgin olurum }\end{array}$ & 81 & 31,0 & 31,2 \\
\hline Vergiye ilişkin ödevlerimi aksattığım için korkarım & 8 & 3,1 & 3,1 \\
\hline Toplam & 260 & 99,6 & 100,0 \\
\hline Kayıp & 1 & 0,4 & \\
\hline Toplam & 261 & 100,0 & \\
\hline
\end{tabular}

Mükelleflerin vergi denetimi için işletmelerine gelindiğinde denetimin sonucu ile ilgili düşüncelerini araştıran soruya verilen cevapların sıklık ve yüzde dağılımı Tablo: 8'de verilmiştir. Buna göre, mükelleflerin \%36,5'i "vergiye ilişkin ödevlerimi yerine getirdiğim için rahat olurum", \%31,2'si "vergiye ilişkin ödevleri yapmış olmak yetmez, denetim elemanı illa ki bir eksiklik bulacağl için tedirgin olurum", \%29,2'si "vergiye ilişkin ödevlerimi yerine getirsem de bir eksiklik çlkar diye tedirgin olurum", \%3,1'i "vergiye ilişkin ödevlerimi aksattığım için korkarım" cevabını vermişlerdir. Mükelleflerin büyük çoğunluğunu (\%36,5'lik “ödevlerimi yerine getirdiğim için rahat olurum” seçeneği dışında kalanlar toplamı \%63,5) vergi denetimlerinde ya ödevlerini yerine tam getirememe ya da denetim elemanı illa ki bir eksiklik bulacağı için tedirginlik yaşadıklarını ifade etmektedirler.

Mükelleflerin vergi denetimi geçirip geçirmediklerini araştıran soruya verdikleri cevapların sıklık ve yüzde dağılımı Tablo: 9'da verilmiştir. Buna göre, mükelleflerin \%40,6's1 "hayır", \%59,4'ü “evet" cevab1 vermişlerdir. Ankete katılan mükelleflerin çoğunluğu vergi denetimi geçirmişlerdir. 
Tablo: 9

Mükelleflerin Vergi Denetimi Geçirme Durumu

\begin{tabular}{|l|c|c|c|}
\hline Vergi denetimi geçirdiniz, mi? & $\begin{array}{c}\text { Siklık } \\
(\boldsymbol{n})\end{array}$ & $\begin{array}{c}\text { Yüzde } \\
(\boldsymbol{\%})\end{array}$ & $\begin{array}{c}\text { Geçerli Yüzde } \\
(\boldsymbol{\%})\end{array}$ \\
\hline Hayır & 104 & 39,8 & 40,2 \\
\hline Evet & 155 & 59,4 & 59,8 \\
\hline & & 159 & 100,0 \\
\hline Toplam & 259 & 99,2 & \\
\hline
\end{tabular}

Tablo: 10

Mükelleflerin Vergi Denetimi İlk Algıları

\begin{tabular}{|c|c|c|c|}
\hline $\begin{array}{l}\text { İşletmenize vergi denetimi için gelindiğini öğrendiğinizde ilk hissettiğiniz } \\
\text { nedir? }\end{array}$ & $\begin{array}{c}\text { Sikllk } \\
(\text { n) }\end{array}$ & $\begin{array}{c}\text { Yüzde } \\
(\%)\end{array}$ & $\begin{array}{l}\text { Geçerli } \\
\text { Yüzde } \\
\text { (\%) }\end{array}$ \\
\hline Tedirgin olurum & 71 & 27,2 & 45,9 \\
\hline Telaşlanırım & 7 & 2,7 & 4,5 \\
\hline Korkarım & 7 & 2,7 & 4,5 \\
\hline Sakin karşı1larım & 45 & 17,2 & 29,0 \\
\hline Hiçbirşey hissetmem & 25 & 9,6 & 16,1 \\
\hline Toplam & 155 & 59,4 & 100,0 \\
\hline Kayıp & 2 & 0,8 & \\
\hline Denetim geçirmeyenler & 104 & 39,8 & \\
\hline Toplam & 261 & 100,0 & \\
\hline
\end{tabular}

Mükelleflerin vergi denetimi için işletmelerine gelindiğinde "ilk hissettikleri duygu ya da ilk algl"larını araştıran soruya verilen cevapların sıklık ve yüzde dağılımı Tablo: 10 'da verilmiştir. Buna göre mükelleflerin \%45,9'u "tedirgin olurum", \%4,5'i "telaşlanırım", \%4,5'i "korkarım", \%29'u "sakin karşılarım", \%16,1'i ise, "hiç bir şey hissetmem" şeklinde cevaplandırmışlardır. Vergi denetimi için gelindiğinde ilk algı olarak hiç bir şey hissetmem ve sakin karşılarım seçenekleri dışında kalan seçenekler tedirginlik, telaş ve korku olarak toplam \%55,5 oranına sahiptir. Sonuç olarak ankete katılan mükelleflerin vergi denetimlerinde ilk algısının tedirginlik şeklinde olduğu söylenebilir.

Vergi denetimi geçiren mükelleflerin, vergi denetimi için işletmelerine gelen denetim elemanının tavrını araştıran soruya verdikleri cevapların sıklık ve yüzde dağılımı Tablo: 11'de verilmiştir. Buna göre mükelleflerin \%40,6's1 "resmi, ciddi ve tarafsız tavır sergiledi”, \%31'i “hatalarımızı gösterip uyarıcı ve ögretici tavır sergiledi”, \%12,3'ü “işimizi aksatan bir tavır sergiledi", \%16,1'i "bizi küçük düşüren bir tavır sergiledi" şeklinde cevaplandırmışlardır. Vergi denetimi için gelen denetim elemanına ilişkin olumlu yargı 
içeren ilk iki seçeneğin toplam \%71,6 oranına sahip olması denetim elemanlarının tavrına ilişkin önemli bir sonuçtur.

Tablo: 11

\section{Denetim Geçiren Mükelleflerin Vergi Denetim Görevlisinin Tavrına İlişkin Düşünceleri}

\begin{tabular}{|c|c|c|c|}
\hline $\begin{array}{l}\text { Vergi denetimi görevlisinin denetim sırasındaki tavır ve davranış hakkında ne } \\
\text { dersiniz? }\end{array}$ & $\begin{array}{c}\text { Siklık } \\
(n)\end{array}$ & $\begin{array}{l}\text { Yüzde } \\
(\%)\end{array}$ & $\begin{array}{c}\text { Geçerl } \\
\text { Yüzde } \\
(\%)\end{array}$ \\
\hline Resmi ciddi tarafsız davranıș sergiledi & 63 & 24,1 & 40,6 \\
\hline Hatalarımızı gösterip uyarıcı ve öğretici tavır sergiledi & 48 & 18,4 & 31,0 \\
\hline İșimizi aksatan bir tavır sergiledi & 19 & 7,3 & 12,3 \\
\hline Bizi küçük düşüren bir tavır sergiledi & 25 & 9,6 & 16,1 \\
\hline Toplam & 155 & 59,4 & 100,0 \\
\hline Denetim geçirmeyenler & 104 & 39,8 & \\
\hline Kayıp & 2 & 0,8 & \\
\hline Toplam & 261 & 100,0 & \\
\hline
\end{tabular}

Tablo: 12

Mükelleflerin Bugün Vergi Denetimi Geçirselerdi Sonuç Tahminine İlişkin Düşünceleri

\begin{tabular}{|c|c|c|c|}
\hline Bugün işletmeniz vergi denetimi geçirmiş olsaydı nasıl sonuçlanırdı? & $\begin{array}{l}\text { Siklık } \\
(n)\end{array}$ & $\begin{array}{l}\text { Yüzde } \\
(\%)\end{array}$ & $\begin{array}{c}\text { Geçerli } \\
\text { Yüzde } \\
(\%)\end{array}$ \\
\hline Vergi ödevlerini eksiksiz yerine getirdiğimiz için sorun çıkmazdı & 130 & 49,8 & 50,2 \\
\hline Vergi ödevlerini eksiksiz yerine getirdiğimizden emin değilim sorun olabilirdi & 23 & 8,8 & 8,9 \\
\hline $\begin{array}{l}\text { Vergi ödevlerini eksiksiz yerine getirsek bile denetim elemanı bir eksiklik } \\
\text { bulurdu }\end{array}$ & 106 & 40,6 & 40,9 \\
\hline Toplam & 259 & 99,2 & 100,0 \\
\hline Kayıp & 2 & 0,8 & \\
\hline Toplam & 261 & 100,0 & \\
\hline
\end{tabular}

Ankete katılan mükelleflerin, "bugün işletmeniz vergi denetimi geçirseydi nasıl sonuçlanırdı?" sorusu ile denetim sonucuna ilişkin tahminlerini araştıran soruya verdikleri cevapların sıklık ve yüzde dağılımı Tablo: 12'de verilmiştir. Buna göre mükelleflerin \%50,4'ü "vergi ödevlerini eksiksiz yerine getirdiğimiz için sorun çıkmazdı", \%41,1'i "vergi ödevlerini eksiksiz yerine getirsek bile denetim elemanı bir eksiklik bulurdu", \%8,5'i "vergi ödevlerini eksiksiz yerine getirdiğimizden emin değilim sorun olabilirdi" şeklinde cevaplandırmışlardır. Mükelleflerin oran olarak yarısı bu gün vergi denetimi geçirselerdi sorun olacağını belirtmişılerdir. 
Tablo: 13

Mükelleflerin Vergi Denetimi Hakkındaki Genel Kanaatleri

\begin{tabular}{|c|c|c|c|}
\hline Vergi denetimi hakkında genel kanaatiniz nedir? & $\begin{array}{c}\text { Sikltk } \\
(n)\end{array}$ & $\begin{array}{l}\text { Yüzde } \\
\text { (\%) }\end{array}$ & $\begin{array}{c}\text { Geçerli Yüzde } \\
\text { (\%) }\end{array}$ \\
\hline Vergi denetimi mükellef üzerine baskı olușturur & 114 & 43,7 & 44,0 \\
\hline Vergi denetimi mükellefin kendini suçluymuş gibi hissetmesine yol açar & 70 & 26,8 & 27,0 \\
\hline Vergi denetimi mükellef için adaletsizlik doğurmaktadır & 32 & 12,3 & 12,4 \\
\hline Vergi denetimi mükellefleri etkilemez & 43 & 16,5 & 16,6 \\
\hline Toplam & 259 & 99,2 & 100,0 \\
\hline Kayıр & 2 & 0,8 & \\
\hline Toplam & 261 & 100,0 & \\
\hline
\end{tabular}

Ankete katılan mükelleflerin, vergi denetimi hakkındaki genel kanaatini araştıran soruya verdikleri cevapların sıklık ve yüzde dağılımı Tablo: 13'te verilmiştir. Buna göre mükelleflerin \%44'ü "vergi denetimi mükellef üzerinde baskı oluşturur", \%27'si “vergi denetimi mükellefin kendisini suçluymuş gibi hissetmesine yol açar", \%12,4'ü "vergi denetimi mükellef için adaletsizlik doğurmaktadır", \%16,6’s1 "vergi denetimi mükellefi etkilemez" şeklinde cevaplandırmışlardır. Ankete katılan mükelleflerin, \%16,6 oranındaki "vergi denetimi mükellefi etkilemez" seçeneği dışında kalan ilk üç seçenek toplamı \%83,4 oranındadır ve mükelleflerin çoğunun denetimler hakkında olumsuz kanaate sahip olduklarını ifade etmektedir.

Tablo: 14

Mükelleflerin Cinsiyet Türüne Göre Vergi Denetimi Hakkındaki Genel Kanaatleri

\begin{tabular}{|l|c|c|c|c|c|c|}
\hline \multirow{2}{*}{\begin{tabular}{l} 
Cinsiyet \\
\cline { 3 - 7 }
\end{tabular}} & $\begin{array}{c}\text { Vergi denetimi hakkındaki genel kanaatiniz nedir? } \\
\text { Vergi denetimi } \\
\text { mükellef } \\
\text { üzerinde bask1 } \\
\text { oluşturur }\end{array}$ & $\begin{array}{c}\text { Vergi denetimi } \\
\text { mükellefin kendini } \\
\text { suçluymuş gibi } \\
\text { hissetmesine yol açar }\end{array}$ & $\begin{array}{c}\text { Vergi denetimi } \\
\text { mükellef için } \\
\text { adaletsizlik } \\
\text { doğurmaktadır }\end{array}$ & $\begin{array}{c}\text { Vergi denetimi } \\
\text { mükellefleri } \\
\text { etkilemez }\end{array}$ & TOPLAM \\
\hline \multirow{2}{*}{ Kadın } & Say1 & 15 & 7 & 1 & 4 & 27 \\
\cline { 2 - 7 } & $(\%)$ & 55,6 & 25,9 & 3,7 & 14,8 & 100,0 \\
\hline \multirow{2}{*}{ Erkek } & Say1 & 99 & 63 & 31 & 39 & 232 \\
\cline { 2 - 8 } & $(\%)$ & 42,7 & 27,2 & 13,4 & 16,8 & 100,0 \\
\hline \multirow{2}{*}{ TOPLAM } & Sayl & 114 & 70 & 32 & 13 & 259 \\
\cline { 2 - 8 } & $(\%)$ & 44,0 & 27,0 & 12,4 & 16,6 & 100,0 \\
\hline
\end{tabular}

Mükelleflerin vergi denetimi hakkında algılarının cinsiyet türüne göre dağılımı Tablo: 14'te görülmektedir. Erkekler kadınlara göre "vergi denetimi mükellef için adaletsizlik doğurmaktadır" seçeneğinde yüksek tercihte bulunmuşlardır. Buna karşılık "vergi denetimi mükellef üzerinde baskı oluşturur" seçeneğinde kadınlar erkeklerden daha yüksek orana sahiptir. 
Tablo: 15

Mükelleflerin Yaş Gruplarına Göre Vergi Denetimi Hakkındaki Genel Kanaatleri

\begin{tabular}{|c|c|c|c|c|c|c|}
\hline \multirow{2}{*}{\multicolumn{2}{|c|}{ Yaş Gruplart }} & \multicolumn{5}{|c|}{ Vergi denetimi hakkındaki genel kanaatiniz nedir? } \\
\hline & & \multirow{2}{*}{\begin{tabular}{|c|}
$\begin{array}{c}\text { Vergi denetimi } \\
\text { mükellef } \\
\text { üzerine bask1 } \\
\text { oluşturur }\end{array}$ \\
42 \\
\end{tabular}} & \multirow{2}{*}{$\begin{array}{c}\begin{array}{c}\text { Vergi denetimi } \\
\text { mükellefin kendini } \\
\text { suçluymuş gibi } \\
\text { hissetmesine yol açar }\end{array} \\
29\end{array}$} & \multirow{2}{*}{$\begin{array}{c}\begin{array}{c}\text { Vergi denetimi } \\
\text { mükellef için } \\
\text { adaletsizlik } \\
\text { doğurmaktadır }\end{array} \\
6\end{array}$} & \multirow{2}{*}{$\begin{array}{c}\begin{array}{c}\text { Vergi denetimi } \\
\text { mükellefleri } \\
\text { etkilemez }\end{array} \\
17\end{array}$} & \multirow{2}{*}{$\begin{array}{c}\text { TOPLAM } \\
94\end{array}$} \\
\hline \multirow{2}{*}{$\begin{array}{l}18-35 \\
\text { Yaş Grubu }\end{array}$} & Say1 & & & & & \\
\hline & $(\%)$ & 44,7 & 30,9 & 6,4 & 18,1 & 100,0 \\
\hline \multirow{2}{*}{\begin{tabular}{|l|}
$36-50$ \\
Yaş Grubu \\
\end{tabular}} & Say1 & 58 & 33 & 22 & 18 & 131 \\
\hline & $(\%)$ & 44,3 & 25,2 & 16,8 & 13,7 & 100,0 \\
\hline \multirow{2}{*}{\begin{tabular}{|l|}
51 ve Üzeri \\
Yaş Grubu \\
\end{tabular}} & Say1 & 12 & 7 & 4 & 7 & 30 \\
\hline & $(\%)$ & 40,0 & 23,3 & 13,3 & 23,3 & 100,0 \\
\hline \multirow{2}{*}{ TOPLAM } & Say1 & 112 & 69 & 32 & 42 & 255 \\
\hline & $(\%)$ & 43,9 & 27,1 & 12,5 & 16,5 & 100,0 \\
\hline
\end{tabular}

Mükelleflerin vergi denetimi hakkında algılarının mükelleflerin yaş gruplarına göre dağılımı Tablo: 15'te görülmektedir. Yaş grubu itibariyle 18-35 genç yaş grubu ve 3650 orta yaş grubu mükelleflerin "vergi denetimi mükellef üzerinde baskı oluşturur" seçeneğinde 51 ve üzeri yaş grubuna göre daha yüksek oranda bask1 hissettiği anlaşılmaktadır. Diğer taraftan "vergi denetimi mükellefin kendini suçluymuş gibi hissetmesine yol açar" seçeneğinde 18-35 yaş grubu genç mükelleflerde tercih oranı diğerlerine göre yüksektir. Buna karşılık, "vergi denetimi mükellef için adaletsizlik doğurmaktadır" seçeneğinde 36-50 orta yaş grubu mükellefler diğerlerine göre yüksek tercihe sahiptir.

Mükelleflerin vergi denetimi hakkında algılarının mükelleflerin öğrenim durumlarına göre dağılımı Tablo: 16'da görülmektedir. Öğrenim durumu itibariyle üniversite mezunları "vergi denetimi mükellef üzerinde baskı oluşturur" seçeneğinde diğer mezunlara göre daha yüksek oranda baskı hissetmektedir. Buna karşılık, "vergi denetimi mükellef için adaletsizlik doğurmaktadır" seçeneğinde ise önlisans mezunu mükellefler diğerlerine göre yüksek tercihe sahiptir. 
Tablo: 16

Mükelleflerin Öğrenim Durumuna Göre Vergi Denetimi Hakkındaki Genel Kanaatleri

\begin{tabular}{|c|c|c|c|c|c|c|}
\hline \multirow{2}{*}{\multicolumn{2}{|c|}{$\begin{array}{l}\text { Ö̆̆renim } \\
\text { Durumu }\end{array}$}} & \multicolumn{5}{|c|}{ Vergi denetimi hakkındaki genel kanaatiniz nedir? } \\
\hline & & \multirow[t]{2}{*}{$\begin{array}{c}\begin{array}{c}\text { Vergi denetimi } \\
\text { mükellef } \\
\text { üzerine bask1 } \\
\text { oluşturur }\end{array} \\
14\end{array}$} & \multirow[t]{2}{*}{$\begin{array}{c}\begin{array}{c}\text { Vergi denetimi } \\
\text { mükellefin kendini } \\
\text { suçluymuş gibi } \\
\text { hissetmesine yol açar }\end{array} \\
11\end{array}$} & \multirow[t]{2}{*}{$\begin{array}{c}\begin{array}{c}\text { Vergi denetimi } \\
\text { mükellef için } \\
\text { adaletsizlik } \\
\text { doğurmaktadır }\end{array} \\
6\end{array}$} & \multirow[t]{2}{*}{$\begin{array}{c}\begin{array}{c}\text { Vergi denetimi } \\
\text { mükellefleri } \\
\text { etkilemez }\end{array} \\
7\end{array}$} & \multirow{2}{*}{$\begin{array}{c}\text { TOPLAM } \\
38\end{array}$} \\
\hline \multirow{2}{*}{ İlköğretim } & Say1 & & & & & \\
\hline & $(\%)$ & 36,8 & 28,9 & 15,8 & 18,4 & 100,0 \\
\hline \multirow{2}{*}{ Lise } & Say1 & 33 & 28 & 7 & 19 & 87 \\
\hline & $(\%)$ & 37,9 & 32,2 & 8,0 & 21,8 & 100,0 \\
\hline \multirow{2}{*}{$\begin{array}{l}\text { Yüksekokul } \\
\text { (Önlisans) }\end{array}$} & Say1 & 14 & 11 & 7 & 5 & 37 \\
\hline & $(\%)$ & \begin{tabular}{ll|}
37,8 \\
\end{tabular} & 29,7 & 18,9 & 13,5 & 100,0 \\
\hline \multirow{2}{*}{$\begin{array}{l}\text { Üniversite } \\
\text { (Lisans) }\end{array}$} & Say1 & 52 & 20 & 12 & 12 & 96 \\
\hline & $(\%)$ & 54,2 & 20,8 & 12,5 & 12,5 & 100,0 \\
\hline \multirow{2}{*}{ TOPLAM } & Say1 & 113 & 70 & 32 & 43 & 258 \\
\hline & $(\%)$ & 43,8 & 27,1 & 12,4 & 16,7 & 100,0 \\
\hline
\end{tabular}

Tablo: 17

Mükelleflerin Denetim Karşısındaki İlk Algılarına Göre Vergi Denetim Elemanının Tavrı Hakkındaki Kanaatleri

\begin{tabular}{|c|c|c|c|c|c|c|}
\hline \multirow{2}{*}{\multicolumn{2}{|c|}{\begin{tabular}{|l|} 
\\
İsletmenize vergi denetimi \\
için gelindiğini \\
ögrendiğinizde ilk \\
hissettiğiniz nedir?
\end{tabular}}} & \multicolumn{5}{|c|}{$\begin{array}{l}\text { Vergi denetimi görevlisinin denetim strasındaki tavır ve davranışı hakkında } \\
\text { ne dersiniz? }\end{array}$} \\
\hline & & \multirow{2}{*}{$\begin{array}{c}\text { Resmi, ciddi, } \\
\text { tarafsız } \\
\text { davranış } \\
\text { sergiledi }\end{array}$} & \multirow{2}{*}{$\begin{array}{c}\text { Hatalarımızı } \\
\text { gösterip uyarıcı ve } \\
\text { öğretici tavır } \\
\text { sergiledi } \\
24 \\
\end{array}$} & \multirow{2}{*}{$\begin{array}{c}\begin{array}{c}\text { İşimizi } \\
\text { aksatan bir } \\
\text { tavır } \\
\text { sergiledi }\end{array} \\
8\end{array}$} & \multirow{2}{*}{$\begin{array}{c}\begin{array}{c}\text { Bizi küçük } \\
\text { düşüren bir } \\
\text { tavır sergiledi }\end{array} \\
15 \\
\end{array}$} & \multirow{2}{*}{$\begin{array}{c}\text { TOPLAM } \\
71\end{array}$} \\
\hline Tediroin olurum & Say1 & & & & & \\
\hline 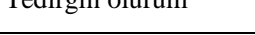 & $(\%)$ & $\mathbf{3 3 , 8}$ & 33,8 & 11,3 & 21,1 & 100,0 \\
\hline \multirow{2}{*}{ Telaşlanırım } & Say1 & 2 & 0 & 4 & 1 & 7 \\
\hline & $(\%)$ & 28,6 & $\mathbf{0 , 0}$ & 57,1 & 14,3 & 100,0 \\
\hline \multirow{2}{*}{ Korkarım } & Sayı & 1 & 2 & 3 & 1 & 7 \\
\hline & $(\%)$ & 14,3 & 28,6 & 42,9 & 14,3 & 100,0 \\
\hline \multirow{2}{*}{ Sakin karşılarım } & Say1 & 25 & 15 & 2 & 3 & 45 \\
\hline & $(\%)$ & 55,6 & 33,3 & 4,4 & 6,7 & 100,0 \\
\hline \multirow{2}{*}{ Hiçbir şey hissetmem } & Say1 & 11 & 7 & 2 & 5 & 25 \\
\hline & $(\%)$ & 44,0 & 28,0 & 8,0 & 20,0 & 100,0 \\
\hline \multirow{2}{*}{ TOPLAM } & Say1 & 63 & 48 & 19 & 25 & 155 \\
\hline & $(\%)$ & 40,6 & $\mathbf{3 1 , 0}$ & 12,3 & 16,1 & 100,0 \\
\hline
\end{tabular}

Mükelleflerin vergi denetimi hakkında ilk algılarının mükelleflerin vergi denetimi hakkındaki kanaatlerine göre dağılımı Tablo: 17'de görülmektedir. Tablodan denetim elemanının tavrı konusunda "resmi, ciddi ve tarafsı davranış sergiledi" ile 
"hatalarımızı gösterip, uyarıcı ve öğretici tavır sergiledi” seçenekleri yüksek oranda olan mükelleflerin, işletmeye denetim için gelindiğinde ilk hissettikleri konusunda "sakin karşılarım" ve "hiçbir şey hissetmem" seçeneklerinin örtüştüğü görülmektedir. Buna karş1lık “işimizi aksatan bir tavır sergiledi” ve "bizi küçük düşüren bir tavır sergiledi” cevabı yüksek oranda olan mükelleflerin denetim için gelindiğinde "telaşlanırım" ve "korkarım" seçeneklerinin paralel bir şekilde yüksek oranda olduğu açıktır. Buradan denetim elemanlarının tavrının mükelleflerin denetimi sakin veya korku ile karşılamasına yol açtıkları, belirleyici oldukları veya mükelleflerin bu tavırlardan etkilendikleri sonucuna ulaşmak mümkündür.

Tablo: 18

\section{Mükelleflerin Vergi Denetimi Hakkındaki Kanaatleri ile Vergi Denetim Elemanının Tavrı Arasındaki İlişki}

\begin{tabular}{|c|c|c|c|c|c|c|}
\hline \multirow{2}{*}{\multicolumn{2}{|c|}{$\begin{array}{l}\text { Vergi denetimi hakkındaki } \\
\text { genel kanaatiniz nedir? }\end{array}$}} & \multicolumn{5}{|c|}{$\begin{array}{l}\text { Vergi denetimi görevlisinin denetim sırasındaki tavır ve davranışı hakkında } \\
\text { ne dersiniz? }\end{array}$} \\
\hline & & \multirow{2}{*}{$\begin{array}{c}\text { Resmi, ciddi, } \\
\text { tarafsız } \\
\text { davranış } \\
\text { sergiledi } \\
29 \\
\end{array}$} & \multirow{2}{*}{$\begin{array}{c}\text { Hatalarımızı } \\
\text { gösterip uyarıcı ve } \\
\text { ögretici tavır } \\
\text { sergiledi } \\
22 \\
\end{array}$} & \multirow{2}{*}{$\begin{array}{c}\text { İşimizi } \\
\text { aksatan bir } \\
\text { tavır } \\
\text { sergiledi } \\
9\end{array}$} & \multirow{2}{*}{$\begin{array}{c}\begin{array}{c}\text { Bizi küçük } \\
\text { düşüren bir } \\
\text { tavir sergiledi }\end{array} \\
10\end{array}$} & \multirow{2}{*}{$\begin{array}{c}\text { TOPLAM } \\
70 \\
\end{array}$} \\
\hline Vergi denetimi mükellef & Say1 & & & & & \\
\hline üzerinde baskı oluşturur & $(\%)$ & 41,4 & 31,4 & 12,9 & 14,3 & 100,0 \\
\hline \multirow{2}{*}{$\begin{array}{l}\text { Vergi denetimi } \\
\text { mükellefin kendini } \\
\text { suçluymuş gibi } \\
\text { hissetmesine yol açar }\end{array}$} & Say1 & 14 & 12 & 5 & 9 & 40 \\
\hline & $(\%)$ & 35,0 & 30,0 & 12,5 & 22,5 & 100,0 \\
\hline \multirow{2}{*}{$\begin{array}{l}\text { Vergi denetimi mükellef } \\
\text { için adaletsizlik } \\
\text { doğurmaktadır }\end{array}$} & Say1 & 6 & 5 & 5 & 3 & 19 \\
\hline & $(\%)$ & 31,6 & 26,3 & 26,3 & 15,8 & 100,0 \\
\hline \multirow{2}{*}{$\begin{array}{l}\text { Vergi denetimi } \\
\text { mükellefleri etkilemez }\end{array}$} & Say1 & 14 & 9 & 0 & 2 & 25 \\
\hline & $(\%)$ & 56,0 & 36,0 & 0,0 & 8,0 & 100,0 \\
\hline \multirow{2}{*}{ TOPLAM } & Say1 & 63 & 48 & 19 & 24 & 154 \\
\hline & $(\%)$ & 40,9 & 31,2 & 12,3 & 15,6 & 100,0 \\
\hline
\end{tabular}

Mükelleflerin vergi denetimi hakkında kanaatleri ile vergi denetim elemanının tavrı arasındaki ilişki Tablo: 18'de görülmektedir. Tablodan denetim elemanının tavrı konusunda "resmi, ciddi ve tarafsı davranış sergiledi" ile "hatalarımızı gösterip, uyarıcı ve ögretici tavır sergiledi" seçenekleri yüksek oranda olan mükelleflerin, "vergi denetimi mükellefleri etkilemez" görüşüne yüksek oranda sahip olması dikkat çekicidir. Bu durum denetim elemanlarının denetim algılarını etkilediklerini göstermektedir.

Mükelleflerin vergi sistemi algıları ile vergi denetim elemanının tavrı arasındaki ilişki Tablo: 19'da görülmektedir. Tablodan, vergi sistemi açısından seçeneklerin hepsinde denetim elemanının tavrı konusunda "resmi, ciddi ve tarafsı davranış sergiledi" ile 
"hatalarımızı gösterip, uyarıcı ve ögretici tavır sergiledi” seçenekleri yüksek oranda olmakla birlikte vergi sistemi için adaletli cevabı veren mükelleflerde daha yüksek orana sahip olduğu görülmektedir.

Tablo: 19

\section{Mükelleflerin Vergi Sistemi Algıları ile Vergi Denetim Elemanının Tavrı Arasındaki İlişki}

\begin{tabular}{|c|c|c|c|c|c|c|}
\hline \multirow{2}{*}{\multicolumn{2}{|c|}{$\begin{array}{l}\text { Size göre Türkiye'de } \\
\text { vergi sistemi }\end{array}$}} & \multicolumn{5}{|c|}{ Vergi denetimi görevlisinin denetim strasındaki tavır ve davranıșı hakkında ne dersiniz? } \\
\hline & & \multirow{2}{*}{$\begin{array}{c}\text { Resmi, ciddi, } \\
\text { tarafsız davranış } \\
\text { sergiledi }\end{array}$} & \multirow{2}{*}{$\begin{array}{c}\text { Hatalarımızı gösterip } \\
\text { uyarıcı ve ögretici tavır } \\
\text { sergiledi } \\
4\end{array}$} & \multirow{2}{*}{\begin{tabular}{|c|}
$\begin{array}{c}\text { İşimizi aksatan } \\
\text { bir tavır } \\
\text { sergiledi }\end{array}$ \\
0 \\
\end{tabular}} & \multirow{2}{*}{$\begin{array}{c}\begin{array}{c}\text { Bizi küçük } \\
\text { düşüren bir } \\
\text { tavır sergiledi }\end{array} \\
0\end{array}$} & \multirow{2}{*}{$\begin{array}{c}\text { TOPLAM } \\
11\end{array}$} \\
\hline \multirow{2}{*}{ Adaletli } & Say1 & & & & & \\
\hline & $(\%)$ & 63,6 & 36,4 & 0,0 & 0,0 & 100,0 \\
\hline \multirow{2}{*}{ Adaletsiz } & Say1 & 41 & 36 & 16 & 18 & 111 \\
\hline & (\%) & 36,9 & 32,4 & 14,4 & 16,2 & 100,0 \\
\hline \multirow{2}{*}{$\begin{array}{l}\text { Kismen } \\
\text { adaletli }\end{array}$} & Say1 & 15 & 8 & 3 & 7 & 33 \\
\hline & $(\%)$ & 45,5 & 24,2 & 9,1 & 21,2 & 100,0 \\
\hline \multirow{2}{*}{ TOPLAM } & Say1 & 63 & 48 & 19 & 25 & 155 \\
\hline & $(\%)$ & 40,6 & 31,0 & 12,3 & 16,1 & 100,0 \\
\hline
\end{tabular}

\section{Sonuç}

Psikolojik vergi sözleşmesi kapsamında vergi uyumu hükümet politikaları, kamu hizmetleri ve vergi otoritesinin mükelleflere muamelesi ile yakından ilgilidir. Vergi otoritesinin mükelleflere muamelesi taraflar arasındaki dayanışmanın düzeyini etkileyeceğinden, vergi otoritesinin mükellefe davranışı mükellefin denetim algısını oluşturarak vergi algısı ve uyumunu şekillendireceği varsayılmaktadır. Bu çalışmada da söz konusu varsayım, Çorum ilinde Ticaret ve Sanayi odasına kayıtlı vergi mükelleflerine yapılan anket doğrultusunda test edilmiştir. 3 temel bölümden oluşan anketin ilk bölümünde ankete katılan mükellefler hakkında genel bilgilere, ikinci bölümde mükelleflerin vergi, vergi sistemi ve vergi yükü algılarına, üçünde bölümde ise mükelleflerin vergi denetimi algıları ve vergi denetimine bakışlarına dair sorulara yer verilmiştir.

Sorulara verilen cevaplar doğrultusunda elde edilen bilgilere göre, ankete katılan mükelleflerin \%59,4'ü vergi denetimi geçirmişlerdir. Vergi denetimi geçiren söz konusu mükelleflerin, vergi denetimi için işletmelerine gelen denetim elemanının tavrı konusundaki görüşleri $\% 40,6$ oranında "resmi, ciddi ve tarafsız" ve $\% 31$ oranında "hataları gösterip uyarıcı ve öğretici tavır sergiledi” şeklinde olmuştur.

Sorulara verilen cevaplar çapraz tablolarla değerlendirildiğinde ise, denetim elemanının "resmi, ciddi ve tarafsız" olduğu ve mükelleflerin "hatalarını gösterip, uyarıcı 
ve ögretici tavır sergilediği”" durumlarda mükelleflerin, işletmeye denetim için gelindiğinde sakin karşıladıkları sonucuna varılmıştır. Aksine denetim elemanının mükellefin "işini aksatan ve mükellefi küçük düşüren tavır sergilediği" durumlarda ise mükelleflerin "telaşlandığı" ve "korktuğu" sonucuna ulaşılmıştır. Bu sonucu doğrular nitelikte bir diğer sonuç ise Tablo: 18'den elde edilmiştir. Bu tabloda denetim elemanının tavrının "resmi, ciddi ve tarafsız" olduğu durumlarda "vergi denetiminin mükellefleri etkilemediğ i" sonucuna varılmıştır. $\mathrm{Bu}$ sonuçlar doğrultusunda vergi denetim elemanlarının tavırlarının mükelleflerin denetim algılarını oluşturarak denetim konusundaki düşüncelerini doğrudan etkilediği varsayımını doğrulamaktadır.

Konu vergi sistemi açısından ele alındığında ise, Tablo: 19 doğrultusunda vergi denetim elemanının tutumunun vergi sisteminin algılanmasında etkili olduğu ve denetim elemanının olumlu tavırlarının vergi sisteminin adil algılanmasına da katkı sağladığı görülmektedir. Böylece psikolojik vergi sözleşmesinin belirttiği gibi vergi otoritesinin mükellefe davranışı mükellefin denetim algısını oluşturarak vergi algısını şekillendirmektedir.

Vergi otoritesinin mükellefe saygılı davranışının vergi uyumu konusundaki etkilerini ise Tablo: 12'de "bugün işletmeniz vergi denetimi geçirseydi nasıl sonuçlanırdı?" sorusuna \%50,4'ünün verdiği ve vergi ödevlerini eksiksiz yerine getirdiklerini beyan ettikleri "vergi ödevlerini eksiksiz yerine getirdiğimiz için sorun çıkmazdı", cevabında görülmektedir.

$\mathrm{Bu}$ sonuçlar, vergi otoritesinin mükellefe davranışı mükellefin denetim algısını oluşturarak vergi algısı ve uyumunu şekillendirdiği varsayımını doğrulamaktadır. Özellikle vergi kayıp ve kaçakları konusunda büyük sorunlar yaşanan ülkemizde vergi uyumunun sağlanmasında vergi denetim elemanlarını tutum ve davranışlarının büyük önem arz ettiğini göstermektedir. Bu kapsamda vergi otoritesi ile işbirliği içinde yapılacak gelecek çalışmalar olumlu adımların atılmasını sağlayabilecektir.

\section{Kaynakça}

Allingham, M.G. \& A. Sandmo (1972), “Income Tax Evasion: A Theoretical Analysis”, Journal of Public Economics, 1, 323-338.

Alm, J. \& G.H. McClelland \& W.D. Schulze (1992), “Why Do People Pay Taxes?”, Journal of Public Economics, 48, 21-38.

Alm, J. \& G.H. McClelland \& W.D. Schulze (1999; 1992), Changing the Social Norm of Tax Compliance by Voting, KYKLOS, 48, 141-171.

Andreoni, J. \& B. Erard \& J. Feinstein (1998), "Tax Compliance”, Journal of Economic Literature, 36(2), 818-860. 
Becker, G.S. (1968), “Crime and Punishment: An Economic Approach”, Journal of Political Economy, 76, 169-217.

Braithwaite, V. (2003), Taxing Democracy, London: Ashgate.

Çiçek, H. \& M. Karakaş \& A. Yıldız (2008), Güney Doğu Anadolu Bölgesi'nde Vergi Yükümlülerinin Vergiyi Algılama ve Tutum Analizi: Bir Alan Araştırması, Ankara, T.C. Maliye Bakanlığı Strateji Geliştirme Başkanlığı, Yayın No. 2008/381.

Elffers, H. \& R.H. Weigel \& D.J. Hessing (1987), “The Consequences of Different Strategies for Measuring Tax Evasion Behavior", Journal of Economic Psychology, 8, 311-37.

Feld, L.P. \& B. Frey (2002), "The Tax Authority and the Taxpayer: An Exploratory Analysis", The 2nd International Conference on Taxation, organized by the Centre for Tax System Integrity of the Australian National University in Canberra, 10-11.

Feld, L. \& B. Frey (2006), "Tax Compliance as the Result of a Psychological Tax Contract: The Role of Incentives and Responsive Regulation", Working Paper, No. 287, Institute for Empirical Research in Economics, University of Zurich.

Feld, L.P. \& B. Frey (2010), “Tax evasion and the Psychological Tax Contract”, J. Alm \& J. Martinez-Vazquez \& B. Torgler (eds.) Developing Alternative Frameworks for Explaining Tax Compliance, London, 74-94.

Friedland, N. (1982), "A Note on Tax Evasion as a Function of the Quality of Information about the Magnitude and Credibility of Threatened Fines: Some Preliminary Research", Journal of Applied Social Psychology, 12, 54-59.

Graetz, M.J. \& L.L. Wilde (1985), “The Economics of Tax Compliance: Facts and Fantasy”, National Tax Journal, 38, 355-63.

Levi, M. (1988), Of Rule and Revenue, University of California Press, Berkeley.

Muter, N.B. \& S. Sakınç \& A.K. Çelebi (1993), Mükelleflerin Vergi Karşısındaki Tutum ve Davranışları Araştırması: Manisa İli Vergi Mükellefleri Üzerine Bir Anket Çalışması, Manisa.

Organ, İ. (2008), Vergi Denetimi ve Türkiye Uygulaması, Gazi Kitabevi Yayını, Ankara.

Polinsky, A.M. \& S. Shavell (2000), “The Fairness of Sanctions: Some implications For Optimal Enforcement Policy", American Law and EconomicsReview, 2, 223-237.

Pommerehne, W.W. \& B. Frey (1992), "The Effects of Tax Administration on Tax Morale", Unpublished Manuscript, University of Zurich.

Roth Jeffrey, A. \& J.T. Scholz \& A.D. Witte (1989), Taxpayer Compliance: An Agenda for Research, University of Pennsylvania Press, Philadelphia.

Schneider, F. (2011), Handbook on the Shadow Economy, Edward Eldar Publishing, Massachusetts, USA.

Slemrod, J. \& S. Yitzhaki (2002), "Tax Avoidance, Evasion and Administration”, Alan J. Auerbach \& Martin Feldstein (eds.), Handbook of PublicEconomics, 3, 1423-70.

Spicer, M.W. \& S.B. Lundstedt (1976), “Understanding Tax Evasion”, Public Finance, 31, 295-304. Şahin, B. (2012), "Metodoloji”, Bilimsel Araştırma Yöntemleri, Ed. Abdurrahman Tanrı̈ğen, Anı Yayınc1lık, 3. Bask1, Ankara. 
Torgler, B. (2011), "Tax Morale and Complaince Review of Evidance and Case Studies for Europe”, Policy Reserach Working Paper, 5922, The World Bank, Human Development Econmics Unit.

Tuay, E. \& İ. Güvenç (2007), Türkiye'de Mükelleflerin Vergiye Bakısı, Ankara, Gelir İdaresi Başkanlığı Mükellef Hizmetleri Başkanlığı, Yayın No. 51.

Varma, K.N. \& A.N. Doob (1998), "Deterring Economic Crimes: The Case of TaxEvasion", Canadian Journal of Criminology, 40, 165-84.

Walsh, K. (2012), Understanding Taxpayer Behaviour - New Opportunities for Tax Administration, <http: //www.esrc.ac.uk/_images/Day2-Session10-Walsh-Understanding-TaxpayerBehaviour-paper_tcm8-33145.pdf>, 22.10.2014.

Yeniçeri, H. (2004), "Beyan Esasına Dayanan Vergilerde Vergi Kayıp ve Kaçaklarının Psikolojik Nedenlerinin Tespitine Yönelik Bir Araştırma", 19. Türkiye Maliye Sempozyumu, Türkiye'de Vergi Kayıp ve Kaçaklarının Önlenmesi Yolları, 10-14 Mayıs 2004, BelekAntalya.

\section{Ekler}

\section{Ek Tablo: 1 \\ Betimleyici İstatistikler}

\begin{tabular}{|c|c|c|c|c|c|c|c|}
\hline & Vergi nedir? & Vergi Yükü & Vergi Sitemi & $\begin{array}{c}\text { Denetimin } \\
\text { Amacı }\end{array}$ & $\begin{array}{c}\text { Denetim için } \\
\text { gelindiğinde ne } \\
\text { düşünürsünüz? }\end{array}$ & $\begin{array}{c}\text { Denetim } \\
\text { geçirdiniz mi? }\end{array}$ & $\begin{array}{l}\text { Kaç kez denetim } \\
\text { geçirdiniz? }\end{array}$ \\
\hline $\begin{array}{l}\text { Geçerli } \\
\text { Sayı }\end{array}$ & 261 & 261 & 261 & 261 & 260 & 261 & 157 \\
\hline Kayıp & 0 & 0 & 0 & 0 & 1 & 0 & 104 \\
\hline Ortalama & 1,98 & 1,20 & 2,15 & 2,61 & 2,01 & 1,41 & 1,85 \\
\hline Medyan & 2,00 & 1,00 & 2,00 & 2,00 & 2,00 & 1,00 & 2,00 \\
\hline Mod & 1 & 1 & 2 & 2 & 1 & 1 & 2 \\
\hline St. Sapma & 1,183 & 0,581 & 0,482 & 1,141 & 0,896 & 0,492 & 0,831 \\
\hline En Küçük & 1 & 1 & 1 & 1 & 1 & 1 & 1 \\
\hline \multirow[t]{2}{*}{ En Büyük } & 6 & 3 & 3 & 5 & 4 & 2 & 4 \\
\hline & $\begin{array}{c}\text { Denetim için } \\
\text { gelindiğinde } \\
\text { ilk algınız? }\end{array}$ & $\begin{array}{c}\text { Denetim } \\
\text { elemanının } \\
\text { tavrı? }\end{array}$ & $\begin{array}{c}\text { Denetim } \\
\text { hakkında genel } \\
\text { kanaatiniz? }\end{array}$ & $\begin{array}{c}\text { Öğrenim } \\
\text { durumunuz? }\end{array}$ & Yaşınız? & Cinsiyetiniz? & $\begin{array}{c}\text { Yaş } \\
\text { Grupları }\end{array}$ \\
\hline $\begin{array}{l}\text { Geçerli } \\
\text { Sayı }\end{array}$ & 157 & 155 & 259 & 260 & 256 & 261 & 256 \\
\hline Kayıp & 104 & 106 & 2 & 1 & 5 & 0 & 5 \\
\hline Ortalama & 2,64 & 2,04 & 2,02 & 2,75 & 39,30 & 1,90 & 1,75 \\
\hline Medyan & 2,00 & 2,00 & 2,00 & 3,00 & 38,00 & 2,00 & 2,00 \\
\hline Mod & 1 & 1 & 1 & 4 & $33(\mathrm{a})$ & 2 & 2 \\
\hline St. Sapma & 1,641 & 1,086 & 1,110 & 1,110 & 9,029 & 0,305 & 0,652 \\
\hline En Küçük & 1 & 1 & 1 & 1 & 19 & 1 & 1 \\
\hline En Büyük & 5 & 4 & 4 & 4 & 70 & 2 & 3 \\
\hline
\end{tabular}


Sağlam, M. \& D. Aytaç (2015), "Vergi Mükelleflerinin Vergi Denetimi Algıları: Çorum Örneği”, Sosyoekonomi, Vol. 23(25), 127-147. 